\title{
Cultural and Linguistic Validation of Foreign Psychometric Instrument -an example of adapting the Suinn-Lew Asian Self-Identity Acculturation (SL-ASIA) Scale, from English to Indonesian Language- ${ }^{1}$
}

\author{
Kwartarini Wahyu Yuniarti ${ }^{2}$ \\ Faculty of Psychology Universitas Gadjah Mada
}

\section{Introduction}

This article is to share best practices of the author in validating foreign research instruments into Indonesian Language. The words of Cultural and Linguistic Validation may not be something new anymore, but the scientific work on the proper cultural and linguistic validation of foreign instruments into Indonesian Language, in Indonesia, especially psychometric instruments, is probably rarely done. Report of that is very limited, if there is any. Nevertheless, any comments and critics to this article are most welcomed.

As we are all aware, as scientists, cultural validity is extremely important in undertaking any assessment bounded to cultural features of the local community. It refers to the fact that translating foreign instrument into the usage for Indonesian community requires not only literal translation, but also cultural and linguistic vali-

\footnotetext{
1 This article is written with a great acknowledgement and depth honor to the generous scientific contribution of Prof Dr Richard Suinn-Lew from the Colorado State University as the founder of the scale and to Prof. Dr. Bernhard Dahme as the supervisor of the author during the time of writing her dissertation in Germany

2 Korespondensi mengenai isi artikel ini dapat melalui:bo_kwy@ugm.ac.id
}

dation. The whole article illustrates the discussions and results of such validation. The fact that the discussion is there somehow shows us that precision of literal translation in most cases is cultural bounded, and therefore revalidation culturally gives significant contribution to the validity of the instrument. One among thousands, even probably millions, psychometric instruments is the Suinn-Lew Asian Self-Identity Acculturation (SLASIA) scale. SL-ASIA Scale is used as the most elaborative example in this article, and ended up with some thoughts of more "homeworks" related to some other foreign instruments in Indonesia.

Richard Suinn and his colleagues developed a 21-item measure of acculturation, titled the Suinn-Lew Asian Self-Identity Acculturation (SL-ASIA) scale. This scale was initially conceptualized for the use with respondents of East Asian background (Chinese, Japanese, and Korean, among others) in the United States. However, most of the items are adaptable to other countries (Suinn, Ahuna, and Khoo, 1992; Suinn, Rickard-Figueroa, Lew, and Vigil, 1987). The items assess the respondent's reported language abilities, language preferences, ethnic self-identity, friendship choices, food preferences, generational status, migration history, cultural preferences, and entertainment prefer- 
ences. These aspects of assessment account for the majority of the variance (Suinn et.al., 1992). Most items incorporate five response options, and all items are keyed in the same direction of acculturation. Dion and Dion (1996) reported that the SLASIA scale has yielded good evidence of internal consistency of reliability (alphas coefficients of .86 or better) with samples of Asian ethnic background at several universities in the West and Midwest of the United States (Atkinson \& Gim, 1989; Suinn et al, 1987, 1992). This scale has been widely used in assessing South East Asian countries. It was also used in various studies related to ethnicity and acculturation (Haudek, C., et al, 1999). The final score can provide information on the values or behavior orientations of the study participants.

The process of linguistic validation provides confidence to ascertain that the translated versions of the instruments will be: (1) culturally relevant to the target country, (2) conceptually equivalent to the original, ensuring cross-cultural equivalence across all versions, and (3) employing language expressions of common use accessible to everybody in the target country (MAPI Annual Report, 2002). This step significantly contributed to identifying possible linguistic and conceptual difficulties of the validated instruments. Experience in linguistic validation has shown that the translation process usually reveals difficulties when adapting the (1) format, (2) instructions, (3) concepts, (4) idiomatic expressions, (5) response scales, or (6) demographic items to different languages (MAPI Annual Report, 2000). Following is the standardized procedure:

- Conceptual definition

- Forward translation: production of two independent translations by two Indonesian translators bilingual in English and in the target language, Indonesian. Results were reconciliated to obtain a consensus version.

- Backward translation: result of the consensus version in the forward translation was then translated back by two other independent translators, English native speakers, bilingual Indonesian, and Australia. Again, results were reconcilliated to obtain a consensus version.

- Comparing results of the version that had been translated back with the original one to gain the best consensus of the semi-final version

- Cognitive Debriefing: undertaking a sort of trial for each item including the face validity of the semi-final version questionnaires. This is done by interviewing persons with similar character of the study participants. This stage is to get feedback whether or not all of the items and the forms of questionnaires were comprehensive, easy to understand and acceptable.

- Re-comparison with the original, then developing the final version of the linguistically validated questionnaires.

Two questionnaires were forward translated by two Indonesian students, bilingual Indonesian-English, female and male, who had been living in English speaking countries previously for 2 and 4 years, respectively, and having different educational backgrounds (Oceanography and Meteorology). The different characters of the translators were deliberately considered to get a maximum variance in producing the forward translations. Discussions on the different interpretation of the translated questionnaires were undertaken afterward.

Compiled versions of the forward translated questionnaires were then trans- 
lated back into the original language. The questionnaire translated back into English, and done by Australian professional translators (students working in a professional company for translations), male and female, bilingual Indonesian-English, both living in Australia but with the experience of having lived in Indonesia for about 5 years. Discussions on the different interpretation of the questionnaires translated back into English were undertaken afterwards via email communications.

Compilation was then carried out to compare with the originals. The pre-final versions were discussed with the translators, both forward- and back-translators independently to construct the final version of the linguistically validated questionnaires.

Following are examples of the process and discussion during validation:

Original

\section{SUINN-LEW ASIAN SELF-IDENTITY ACCULTURATION SCALE} (SL-ASIA): Indonesian Revision

Translator 1

\section{SKALA AKULTURASI IDENTITAS DIRI ASIA oleh Suinn-Lew (SL-ASIA): Indonesian Revision}

Translator 2

SKALA AKULTURASI KEPRIBADIAN ASIA SUINN - LEW

(SL - ASIA) : Revisi dalam bahasa Indonesia

Compiled version

\author{
SKALA AKULTURASI SUINN-LEW \\ DALAM \\ IDENTITAS DIRI ASIA \\ (SL-ASIA): Versi Indonesia
}

Discussion

The wording "Self-Identity" was translated as "Identitas Diri" (English: Self-Identity) by translator 1 and "Kepribadian" (English: Personality) by translator 2. It was then discussed what is meant by "Self-identity" and what is meant by "Personality". Most people (lay people) thought that the wording of "Self-identity" and "Personality" are somehow "similar". After clarification was made, we agreed to translate it into "Identitas Diri" (in English this would be "self-identity").

INSTRUCTIONS: The questions which follow are for the purpose of collecting information about your historical background as well as more recent behaviors which may be related to your cultural identity. Please kindly give a mark $(X)$ to one of the options which best described you.

\section{Translator 1}

PETUNJUK: Pertanyaan-pertanyaan berikut ini ditujukan untuk mengumpulkan informasi tentang latar belakang sejarah anda dan tingkah laku terkini yang mungkin berhubungan dengan identitas budaya anda. Tolong berikan tanda (X) pada salah satu pilihan yang paling menggambarkan diri anda.

\section{Translator 2}

Instruksi : Pertanyaan - pertanyaan dibawah ini bertujuan untuk mengumpulkan informasi baik mengenai latar belakang hidup Anda maupun perilaku perilaku terakhir Anda yang bisa dihubungkan dengan identitas kultur Anda. Berilah tanda ( $\mathrm{x}$ ) untuk salah satu dari pilihan - pilihan yang paling tepat menggambarkan Anda. 
Compiled version

PETUNJUK: Pertanyaan - pertanyaan dibawah ini bertujuan untuk mengumpulkan informasi baik mengenai latar belakang hidup Anda maupun perilaku Anda pada akhir-akhir ini yang bisa dihubungkan dengan identitas kultur Anda. Berilah tanda silang (x) pada salah satu pilihan, yang paling tepat menggambarkan Anda.

\section{Discussion}

"Instruction" would be literally "Instruksi" in Indonesian. However, "Instruksi" in Indonesian would be strongly associated with the impression of being controlled by the instructor, and I supposed the meaning expressed in the word "Instruction" is more like "Guidance", giving information on what the scale is about and on how to deal with it. With regard to this thought, the closest wording in translating the word "instruction" is "Petunjuk", which literally means "Guide" in English.

The way of translating plurals from English to Indonesian is by simply writing the word twice in Indonesia, because we do not have any specific expression for the plural form. Because of that, the wording "behaviours" was translated into perilakuperilaku. However, this translation sounds a little bit "strange" to Indonesians. The word "behaviour" ("perilaku") itself, with or without indicator plural can be perceived as plural as well in Indonesian. The contextual meaning embodied within the paragraph also helps people understand whether a word in Indonesian is meant as plural or singular. In this regard, the wording "perilaku" can be perceived as plural without repeating it twice.

The following phrases are discussed with regard to their connotation of the in- tonation and cultural embodiment of "as a request" or "as an order"

- "Please kindly give a mark $(X)$ to one of the options which best describes you."

- "Tolong berikan tanda $(X)$ pada salah satu pilihan yang paling menggambarkan diri anda."

- "Berilah tanda (x) untuk salah satu dari pilihan - pilihan yang paling tepat menggambarkan Anda."

It was finally agreed that the word "please" is not really meant as "asking for help" in Indonesian, but it is meant to tell the respondent what to do. It was realised that somehow in English the word "please" in that particular sentence is meant to "ask for help politely" and to ask the respondent to do something. However, the meaning would be changed in Indonesian if it would be translated literally as "asking for help". Therefore, the compiled forward translation has used a more imperative sentence without reducing the politeness of the wording: "Berilah tanda silang $(x)$ pada salah satu pilihan, yang paling tepat menggambarkan Anda." Which would simply mean "Give a mark $(X)$ to one of the options which best describes you."

\section{Original}

(NOTE: "Western" refers to English, German, French, Spanish, American, etc.)

\section{Translator 1}

(CATATAN: "Barat" berarti Inggris, Jerman, Perancis, Spanyol, Amerika dll.)

\section{Translator 2}

(Perhatian: "Barat" berarti Inggris, Jerman, Perancis, Spanyol, Amerika, dsb.) 
Compiled version

(CATATAN: "Barat" berarti Inggris, Jerman, Perancis, Spanyol, Amerika dll.)

\section{Discussion}

No different interpretation* occurred in this part. Tranlator 2, however, had translated the "Note" into "Perhatian" ("Attention"), which was then discussed and it was agreed to keep it as "Catatan" ("Note")

* : all items having "no diferent interpretation", will not be presented more in this article

\section{Original}

1. What language can you speak?

- Indonesian only

- Mostly Indonesian, some English or German

- Indonesian and English or German about equally well (bilingual)

- Mostly English or German, some Indonesian

- Only English or German

\section{Translator 1}

1. Bahasa apa yang anda kuasai?

- Hanya bahasa Indonesia

- Kebanyakan bhs Indonesia, sedikit bhs Inggris atau Jerman

- Bhs Indonesia dan Inggris atau Jerman kurang lebih sama (dwibahasa)

- Kebanyakan bhs Inggris atau Jerman, sedikit bhs Indonesia

- Hanya bahasa Inggris atau Jerman

Translator 2

1. Berbahasa apakah Anda?

- Hanya berbahasa Indonesia

- Sebagian besar berbahasa Indonesia, sebagian kecil berbahasa Ing- gris atau Jerman

- Bahasa Indonesia dan Inggris atau Jerman, kurang lebih, pada tingkat kemampuan yang sama (dua bahasa)

- Sebagian besar berbahasa Inggris atau Jerman, sebagian kecil berbahasa Indonesia

- Hanya berbahasa Inggris atu Jerman

\section{Compiled version}

1. Bahasa apa yang anda kuasai?

- Hanya menguasai bahasa Indonesia

- Sangat menguasai bahasa Indonesia, hanya sedikit menguasai bahasa Inggris atau Jerman

- Bahasa Indonesia dan Inggris atau Jerman kurang lebih sama (bilingual)

- Sangat menguasai bahasa Inggris atau Jerman, sedikit menguasai bahasa Indonesia

- Hanya menguasai bahasa Inggris atau Jerman

\section{Discussion}

"What language can you speak?" was interpreted literally by one of the translators as "What language do you use". After reading item number 2 , and trying to get a better understanding of the embodied meaning in the question number 1 , we translated literally in Indonesian as "What language have you been mastering" or: you have mastered; in Indonesian there is no different between "you have mastered" and "you have been mastering", because we have no grammatical tenses. The way we indicate the "tenses" in our language is simply by adding the time reference explicitly)". The answers are being adjusted. 
Original

2. What language do you prefer?

- Indonesian only

- Mostly Indonesian, some English or German

- Indonesian and English or German about equally (bilingual)

- Mostly English or German, some Indonesian

- Only English or German

\section{Translator 1}

2. Bahasa mana yang anda sukai?

- Hanya bahasa Indonesia

- Kebanyakan bhs Indonesia, sedikit bhs Inggris atau Jerman

- Bhs Indonesia dan Inggris atau Jerman kurang lebih sama (dwibahasa)

- Kebanyakan bhs Inggris atau Jerman, sedikit bhs Indonesia

- Hanya bahasa Inggris atau Jerman

\section{Translator 2}

2. Bahasa apakah yang lebih Anda suka?

- Hanya bahasa Indonesia

- Sebagian besar bahasa Indonesia, sebagian kecil bahasa Inggris atau Jerman

- Bahasa Indonesia dan Inggris atau Jerman, kurang lebih, pada tingkat kesukaaan yang sama (dua bahasa)

- Sebagian besar bahasa Inggris atau Jerman, sebagian kecil bahasa Indonesia

- Hanya bahasa Inggris atu Jerman

\section{Compiled version}

2. Bahasa mana yang lebih banyak Anda pakai?

- Hanya bahasa Indonesia

- Sangat lebih sering bahasa Indonesia, cuman kadang-kadang bahasa Inggris atau Jerman

- Bahasa Indonesia dan Inggris atau
Jerman kurang lebih sama (bilingual)

- Sangat lebih sering bahasa Inggris atau Jerman, cuman kadang-kadang bahasa Indonesia

- Hanya bahasa Inggris atau Jerman

\section{Discussion}

The "word" "prefer" is meant to be used as "prefer to use". It was initially translated literally as "sukai" (Translator1) and "use" (Translator - 2) which is actually not what it is supposed to mean. However, to put it in Indonesian, we need to explicitly mention this. Therefore the translation is "Which language do you more frequently use" ("Bahasa mana yang lebih banyak Anda pakai").The options have been adjusted according to the wording as well as the scale.

Original

3. How do you identify yourself?

- South East Asian

- Indonesian

- Bicultural (Indonesian-Westerner)

- Javanese-Westerner, SundaneseWesterner, Batak-Westerner, Timorese-Westerner, BugisWesterner or any other combination between your tribe and a Westerner

- Westerner

Translator 1

3. Bagaimana anda mengindentifikasikan diri anda sendiri?

- Asia Tenggara

- Indonesia

- Dwi-Budaya (Indonesia-Barat)

- Jawa-Barat, Sunda-Barat, BatakBarat, Timor-Barat, Bugis-Barat atau kombinasi lain dari suku anda dengan budaya Barat

- Barat 
Translator 2

3. Bagaimanakah Anda mengidentifikasikan diri Anda?

- Orang Asia Tenggara

- Orang Indonesia

- Orang berkultur dua (Indonesia Barat)

- Orang Jawa - Barat, Sunda - Barat, Batak - Barat, Timor Timur - Barat, Bugis - Barat atau perpaduan antra suku lain dengan seorang Barat

- Orang Barat

\section{Compiled version}

3. Bagaimana anda mengindentifikasikan diri anda sendiri?

- Orang Asia Tenggara

- Orang Indonesia

- Orang Dua-Budaya (IndonesiaBarat)

- Orang Jawa-Barat, atau gabungan Sunda dan Barat, atau Batak dan Barat, Tatau orang Timor dan Barat, atau orang Bugis dan Barat, atau kombinasi lain dari suku anda dengan budaya Barat

- Orang Barat

\section{Discussion}

One of the translators translated it literally from English "How do you identify yourself" (Translator 2) and "How do you identify you yourself" (Translator 1). There was no different interpretation of the item. It was then decided to use the form of translator 1 , stressing the internal self perception and NOT the identification "from other people around you" in Indonesia.

There is also a need to explicitly mention the Indonesian word "orang" ("person") attached to each option referring to the origin or culture or location of the society in which the person has a sense of be- longing. Literally translated into English the $1^{\text {st }}$ option would mean, "Person SouthEast Asia", etc, otherwhise it would be interpreted as "direction" in Indonesian, like for example North, East, West, South, etc, and not having the meaning of the person attached in the wording. The other options are adjusted accordingly.

\section{Original}

4. Which identification does (did) your mother use?

- South East Asian

- Indonesian

- Bicultural (Indonesian-Westerner)

- Javanese-Westerner, SundaneseWesterner, Batak-Westener, Timorese-Westener, BugisWesterner or any other combination between your tribe and a Westerner)

- Westerner

\section{Translator 1}

4. Identitas apa yang dipakai ibu anda?

- Asia Tenggara

- Indonesia

- Dwi-Budaya (Indonesia-Barat)

- Jawa-Barat, Sunda-Barat, BatakBarat, Timor-Barat, Bugis-Barat atau kombinasi lain dari suku anda dengan budaya Barat

- Barat

\section{Translator 2}

4. Identifikasi apakah yang dipakai oleh ibu Anda?

- Orang Asia Tenggara

- Orang Indonesia

- Orang berkultur dua (Indonesia Barat)

- Orang Jawa - Barat, Sunda - Barat, Batak - Barat, Timor Timur - Barat, Bugis - Barat atau perpaduan antra suku lain dengan seorang Barat 
- Orang Barat

\section{Compiled version}

4. Identifikasi-diri yang mana yang dipakai oleh ibu Anda?

- Orang Asia Tenggara

- Orang Indonesia

- Orang Dua-Budaya (IndonesiaBarat)

- Orang Jawa-Barat, atau gabungan Sunda dan Barat, atau Batak dan Barat, Tatau orang Timor dan Barat, atau orang Bugis dan Barat, atau kombinasi lain dari suku anda dengan budaya Barat

- Orang Barat

Discussion

Similar modifications were made to mention the word "person" ("orang" in Indonesian) explicitly in the options.

\section{Original}

6. What was the ethnic origin of the friends and peers you had, as a child up to age 6 ?

- Almost exclusively Indonesians

- Mostly Indonesians

- About equally Indonesian and Westerner groups

- Mostly Westerners

- Almost exclusively Westerners

Translator 1

6. Apa asal suku dari teman-teman dan kerabat yang dulu anda miliki sewaktu kecil hingga umur 6 th?

- Hampir seluruhnya Indonesia

- Kebanyakan Indonesia

- Sebanding antara kelompok Indonesia dan Barat

- Kebanyakan Barat

- Hampir seluruhnya Barat
Translator 2

6. Darimanakah asal suku (etnis) teman teman dan teman bermain Anda, ketika berusia diatas 6 tahun?

- Hampir semuanya orang Indonesia

- Sebagian besar orang Indonesia

- Orang Indonesia dan Barat, kurang lebih, dalam jumlah yang sama

- Sebagian besar orang Barat

- Hampir semuanya orang Barat

Compiled version

6. Apa asal suku dari teman-teman dan kerabat yang dulu anda miliki sewaktu kecil hingga umur 6 th?

- Hampir seluruhnya Indonesia

- Kebanyakan Indonesia

- Sebanding antara kelompok Indonesia dan Barat

- Kebanyakan Barat

- Hampir seluruhnya Barat

\section{Discussion}

"What was ...." in English would be literally translated in Indonesian as "Apa...". However, the meaning embodied in the wording of "What was the origin..." in the item was "where did they come from". Simply putting "Apa..." in Indonesian would sound a little bit unfamiliar in the day to day language of the people. Therefore, the translation used for this item, would literally mean "From what tribes of your friends and peers ....." ("Apa asal suku dari teman-teman dan kerabat ........")in English.

The translation of the options were adjusted to the graduation of the scale.

\section{Original}

8. Whom do you now associate with in the community?

- Almost exclusively Indonesians

- Mostly Indonesians 
- About equally Indonesian and Westerner groups

- Mostly Westerners

- Almost exclusively Westerners

\section{Translator 1}

8. Dengan siapa anda sekarang menghubungkan diri anda dalam lingkungan?

- Hampir seluruhnya Indonesia

- Kebanyakan Indonesia

- Sebanding antara kelompok Indonesia dan Barat

- Kebanyakan Barat

- Hampir seluruhnya Barat

Translator 2

8. Dengan siapakah Anda berhubungan dalam masyarakat, saat ini ?

- Hampir semuanya orang Indonesia

- Sebagian besar orang Indonesia

- Orang Indonesia dan Barat, kurang lebih, dalam jumlah yang sama

- Sebagian besar orang Barat

- Hampir semuanya orang Barat

Compiled version

8. Dengan kelompok budaya manakah pada saat sekarang ini Anda lebih banyak berkomunikasi dalam masyarakat?

- Hampir seluruhnya dengan orang Indonesia

- Kebanyakan orang Indonesia

- Sebanding antara kelompok orang Indonesia dan Barat

- Kebanyakan dengan orang Barat

- Hampir seluruhnya orang Barat

\section{Discussion}

The word "associate" is literally translated as "..connecting yourself to.." by one of the translators ("..menghubungkan diri..") and "..making relationship or asso- ciation with ...in the society.." by the other ("..you, making relationship with .." or "...you, associating with.."). The second wording was then decided to be used in the final version. Nevertheless, this will be examined in the translation back into English as to its linguistic precision and cultural-embodiment.

\section{Original}

9. If you could pick, whom would you prefer to associate with in the community?

- Almost exclusively Indonesians

- Mostly Indonesians, South East Asians

- About equally Indonesian and Westerner groups

- Mostly Westerners

- Almost exclusively Westerners

Translator 1

9. Jika anda dapat memilih, dengan siapa anda lebih cocok menghubungkan diri anda dalam lingkungan?

- Hampir seluruhnya Indonesia

- Kebanyakan Indonesia

- Sebanding antara kelompok Indonesia dan Barat

- Kebanyakan Barat

- Hampir seluruhnya Barat

\section{Translator 2}

9. Jika Anda dapat memilih, dengan siapakah Anda lebih suka untuk berhubungan dalam masyarakat?

- Hampir semuanya orang Indonesia

- Sebagian besar orang Indonesia

- Orang Indonesia dan Barat, kurang lebih, dalam jumlah yang sama

- Sebagian besar orang Barat

- Hampir semuanya orang Barat 
Compiled version

9. Seandainya Anda dapat memilih, maka dengan kelompok budaya manakah Anda akan lebih banyak berkomunikasi dalam masyarakat?

- Hampir seluruhnya dengan orang Indonesia

- Kebanyakan orang Indonesia

- Sebanding antara kelompok orang Indonesia dan Barat

- Kebanyakan dengan orang Barat

- Hampir seluruhnya orang Barat

\section{Discussion}

The 1st translator has translated the "community" into "environment" ("lingkungan") in Indonesian. The $2^{\text {nd }}$ translator translated it into "community or society" ("masyarakat"). Although in this context, both "lingkungan" or "masyarakar or society" yield similar meanings, "community" seems to be the best choice among these three possibilities. And therefore, the final translation is "..masyarakat..".

\section{Original}

10. What is your music preference?

- Only Indonesian

- Mostly Indonesian

- Equally Indonesian and Western

- Mostly Western

- Western only

Translator 1

10. Apa musik kesukaan anda?

- Hanya Indonesia

- Kebanyakan Indonesia

- Sebanding antara Indonesia dan Barat

- Kebanyakan Barat

- Hanya barat

\section{Translator 2}

10. Musik apakah yang Anda suka?
- Hanya Indonesia

- Sebagian besar Indonesia

- Indonesia dan Barat pada tingkat kesukaan yang sama

- Sebagian besar Barat

- Hanya Barat

Compiled version

10. Apa musik kesukaan anda?

- Hanya musik Indonesia

- Sebagian besar musik Indonesia

- Sebanding antara musik Indonesia dan Barat

- Sebagian besar musik Barat

- Hanya musik barat

\section{Discussion}

The word "preference" would be literally translated as "will select ..", it does mean however that whatever is going to be "selected" is assumed to be something that he or she likes better. In Indonesian, the translation is "like", as "being preferred" in English or "suka" in Indonesian.

In this context, we also need to mention the Indonesian word "music" explicitly, otherwise it would be interpreted as "direction" like "West, East, South and North". Therefore, it is translated into "Indonesian music" ("musik Indonesia"), etc.

\section{Original}

14. What contact have you had with Indonesia?

- Raised one year or more in Indonesia

- Lived for less than one year in Indonesia

- Occasional visits to Indonesia

- Occasional communications (letters, phone calls, etc.) with people in Indonesia

- No exposure or communications with people in Indonesia 
Translator 1

14. Kontak apa yang anda miliki dengan orang Indonesia?

- Dibesarkan setahun atau lebih di Indonesia

- Hidup kurang dari setahun di Indonesia

- Kunjungan kadang-kadang ke Indonesia

- Komunikasi kadang-kadang (surat, telefon, dll.) dengan orang di Indonesia

- Tidak ada hubungan atau komunikasi dengan orang di Indonesia

Translator 2

14. Hubungan seperti apakah yang Anda miliki dengan Indonesia?

- Dibesarkan satu tahun atau lebih di Indonesia

- Hidup kurang dari satu tahun di Indonesia

- Sesekali mengunjungi Indonesia

- Sesekali berkomunikasi (dalam surat, pembicaraan di telefon, dsb.) dengan orang - orang di Indonesia

- Tidak ada hubungan atau komunikasi dengan orang - orang di Indonesia

Compiled version

14. Dalam bentuk apa Anda memiliki hubungan dengan Indonesia?

- Dibesarkan selama satu tahun atau lebih di Indonesia

- Hidup kurang dari satu tahun di Indonesia

- Kadang-kadang mengunjungi Indonesia

- Kadang-kadang berkomunikasi (dalam surat, pembicaraan di telefon, dsb.) dengan orang - orang di Indonesia
- Tidak ada hubungan atau komunikasi dengan orang - orang di Indonesia

\section{Discussion}

The word "contact" would be literally translated as "kontak" in Indonesian. However, this word does not sound too "nice" to Indonesians, it is just not commonly used in this context, although it may still yield the embodied meaning of "contact" in English. The other possibility is to translate it as "relationship" ("hubungan") in Indonesian. But then "relationship" may be associated with a stronger relation compared to the original word, "contact". With regard to this issue, we decided to translate it into "Dalam bentuk apa anda..", which would be literally in English as follows: "In what form or what kind of relationship ......".

\section{Original}

15. What is your food preference at home?

- Exclusively Indonesian food

- Mostly Indonesian food, some western food

- About equally Indonesian and western food

- Mostly western food

- Exclusively western food

\section{Translator 1}

15. Apa masakan kesukaan anda di rumah?

- Khususnya masakan Indonesia

- Kebanyakan masakan Indonesia, sedikit masakan Barat

- Seimbang antara masakan Indonesia dan Barat

- Kebanyakan masakan Barat

- Khususnya maskan Barat 
Translator 2

15. Apakah makanan kesukaan Anda di rumah?

- Hanya makanan Indonesia

- Sebagian besar makanan Indonesia, sebagian kecil makanan Barat

- Makanan Indonesia dan Barat, pada tingkat kesukaan yang sama

- Sebagian besar makanan Barat

- Hanya makanan Barat

Compiled version

15. Apakah makanan kesukaan Anda di rumah?

- Hanya makanan Indonesia

- Sebagian besar makanan Indonesia, sedikit makanan Barat

- Seimbang antara makanan Indonesia dan makanan Barat

- Sebagian besar makanan Barat

- Hanya makanan Barat

Discussion

The discussion was about the different interpretation in translating the word "food". Food as a product ("makanan" in Indonesian") or food in relation to the way it was cooked ("masakan" in Indonesian). "Masakan" may use food products which are not typically Indonesian or Asian, but the way it is cooked can be using an Indonesian or Asian style of cooking. In this case, it seems to us that what is meant in the original is "food" as a product. It does not matter how it was cooked. With regard to this, we decided to select "makanan" in translating the word "food".

Discussion on the word "preference" was carried out as for the previous items.

No essential discussion on the options of the answers.
Original

19. If you consider yourself an Indonesian, how much pride do you have in this sense of belonging?

- Extremely proud

- Moderately proud

- Little pride

- No pride but I do not feel negative towards Indonesia

- No pride and I have negative feelings towards Indonesia

\section{Translator 1}

19. Jika anda menganggap diri anda sebagai orang Indonesia, seberapa besar kebanggaan yang anda miliki?

- Sangat bangga

- Cukup bangga

- Sedikit bangga

- Tidak bangga tanpa perasaan negatif terhadap Indonesia

- Tidak bangga dengan perasaan negatif terhadap Indonesia

Translator 2

19. Jika Anda memandang diri Anda sebagai seorang Indonesia, seberapa besarkah kebanggaan yang Anda punyai dalam hal memiliki ?

- Sangat bangga

- Cukup bangga

- Sedikit bangga

- Tidak ada kebanggaan tetapi tidak mempunyai perasaan negatif terhadap Indonesia

- Tidak ada kebanggaan tetapi merasa negatif terhadap Indonesia

\section{Compiled version}

19. Jika Anda memandang diri Anda sebagai seorang Indonesia, seberapa besarkah kebanggaan yang Anda miliki masuk dalam kelompok dengan identitas orang Indonesia? 
- Sangat bangga

- Cukup bangga

- Sedikit bangga

- Tidak ada kebanggaan tetapi tidak mempunyai perasaan negatif terhadap Indonesia

- Tidak ada kebanggaan, dan bahkan memiliki perasaan negatif terhadap Indonesia

\section{Discussion}

It was difficult to translate the word "sense of belonging" using common Indonesian language. It was initially interpreted by one of the translators as "having things". We finally translated it into "...masuk dalam kelompok dengan identitas orang Indonesia". In English this would literally mean ".....entering a group with Indonesia as it's identity".

It was also discussed whether the wording "feel negative" in the options can be translated as "dislike" ?. This has not been decided. It is tentatively translated as "having negative feelings ("memiliki perasaan negative"), however, it will be crosschecked during the cognitive debriefing which wording is commonly accepted more easily by lay people in Indonesia without omitting the meaning embodied in the context.

\section{Original}

20. How would you rate yourself?

- Very Indonesian

- Mostly Indonesian

- Bicultural

- Mostly Westernized

- Very Westernized

\section{Translator 1}

20. Bagaimana anda mengukur diri anda?

- Sangat Indonesia

- Cukup Indonesia
- Dwi budaya

- Cukup Barat

- Sangat Barat

Translator 2

20. Bagaimanakah Anda mengurutkan diri Anda?

- Sangat ke-Indonesiaan

- Sebagian besar ke - Indonesiaan

- Bebudaya dua

- Sebagian besar ke - Barat-baratan

- Sangat ke - Barat-baratan

Compiled version

20. Bagaimana Anda menempatkan diri sendiri dalam urutan di bawah ini:

- Sangat Indonesia

- Cukup Indonesia

- Dua budaya

- Cukup Barat

- Sangat Barat

\section{Discussion}

The word "rate" in English could be literally translated as "measuring.." or "..rank" in Indonesian. However, we discussed that the best translation for this item is (in English )"..how would you put yourself in this following order...." (In Indonesian: "Bagaimana Anda menempatkan diri sendiri dalam urutan di bawah ini..."

\section{Original}

22. Rate yourself on how much you believe in Indonesian values (e.g., about marriage, families, education, work): 1 2 (do not believe)

345

(strongly believe in Indonesian values) 
Translator 1

22. Ukur diri anda sendiri seberapa besar anda percaya tata nilai Indonesia (seperti tentang pernikahan, keluarga, pendidikan, pekerjaan:

12

(tidak percaya)

345

(sangat percaya pada nilai Indonesia)

\section{Translator 2}

22. Urutkan diri Anda dalam sebagaimana besarkah Anda mempercayai nilai nilai Indonesia(misalnya, dalam hal pernikahan, keluarga, pendidikan, pekerjaan) :

12

(tidak percaya)

345

(sangat percaya pada nilai Indonesia)

\section{Compiled version}

22. Ukurlah diri anda sendiri, seberapa besar anda percaya tata nilai Indonesia (seperti tentang pernikahan, keluarga, pendidikan, pekerjaan:

12

(tidak percaya)

345

(sangat percaya pada nilai Indonesia)

\section{Discussion}

A "little" problem occurred for this item regarding the word "families". In Indonesian "Families" would also include "relatives". So, we were not very sure whether this "families" translation is not changing the meaning embodied in the word "families" in English. This requires further discussion, both during and after the cognitive debriefing of this scale.
Original

26. There are many different ways in which people think of themselves. Which ONE of the following most closely describes how you view yourself?

- I consider myself basically an Indonesian person. Even though I live and work in a western country, I still view myself basically as an Indonesian person.

- I consider myself basically as a Westerner. Even though I have an Indonesian background and characteristics, I still view myself basically as a Westerner.

- I consider myself as a Bicultural, although deep down I always know I am an Indonesian.

- I consider myself as a Bicultural, although deep down, I view myself as a Westerner.

- I consider myself as a Bicultural. I have both Indonesian and Western characteristics, and I view myself as a blend of both.

\section{Translator 1}

26. Ada berbagai cara orang menganggap dirinya sendiri. Yang mana salah SATU dari yang berikut ini paling menggambarkan bagaimana anda memandang diri anda sendiri?

- Saya menganggap diri saya pada dasarnya orang Indonesia. Meskipun saya hidup dan bekerja di negara Barat, saya masih memandang diri saya pada dasarnya sebagai orang Indonesia.

- Saya menganggap diri saya pada dasarnya sebagai orang Barat. Walaupun saya memiliki latar belakang dan karakter Indonesia, saya masih memandang diri saya pada dasarnya sebagai seorang Barat. 
- Saya menganggap diri saya sebagai orang campuran, walaupun dalam diri saya, saya tahu bahwa saya seorang Indonesia.

- Saya menganggap diri saya sebagai orang campuran, walaupun dalam diri saya, saya memandang diri saya sebagai orang Barat.

- Saya menganggap diri saya sebagai campuran. Saya punya karakter Indonesia dan Barat dan memandang diri saya sebagai campuran keduanya.

\section{Translator 2}

26. Ada terdapat banyak cara orang memandang dirinya. Manakah dari yang dibawah ini yang paling mendekati gambaran bagaimana Anda memandang diri Anda?

- Saya melihat diri saya, pada dasarnya, sebagai seorang Indonesia. Walaupun saya hidup dan bekerja di sebuah negara Barat, saya tetap melihat diri saya, pada dasarnya, sebagai seorang Indonesia

- Saya melihat diri saya, pada dasarnya, sebagai seorang Barat. Walaupun saya memiliki latar belakang dan ciri - ciri Indonesia, saya tetap melihat diri saya, pada dasarnya, sebagai seorang Barat

- Saya memandang diri saya sebagai orang yang berbudaya ganda, walaupun jauh di lubuk hati saya selalu tahu saya adalah seorang Indonesia

- Saya memandang diri saya sebagai orang yang berbudaya ganda, walaupun jauh di lubuk hati saya selalu tahu saya adalah seorang Barat

- Saya memandang diri saya sebagai orang yang berbudaya ganda. Saya memiliki baik ciri - ciri Indonesia dan Barat, dan saya melihat diri saya sebagai gabungan dari keduanya

\section{Compiled version}

26. Ada terdapat banyak cara orang memandang dirinya. Manakah dari yang dibawah ini yang paling mendekati gambaran bagaimana Anda memandang diri Anda sendiri?

- Saya melihat diri saya, pada dasarnya, sebagai seorang Indonesia. Walaupun saya hidup dan bekerja di sebuah negara Barat, saya tetap melihat diri saya, pada dasarnya, sebagai seorang Indonesia

- Saya melihat diri saya, pada dasarnya, sebagai seorang Barat. Walaupun saya memiliki latar belakang dan ciri - ciri Indonesia, saya tetap melihat diri saya, pada dasarnya, sebagai seorang Barat

- Saya memandang diri saya sebagai orang yang berbudaya ganda, walaupun jauh di lubuk hati saya selalu tahu saya adalah seorang Indonesia

- Saya memandang diri saya sebagai orang yang berbudaya ganda, walaupun jauh di lubuk hati saya selalu tahu saya adalah seorang Barat

- Saya memandang diri saya sebagai orang yang berbudaya ganda. Saya memiliki baik ciri - ciri Indonesia dan Barat, dan saya melihat diri saya sebagai gabungan dari keduanya

\section{Discussion}

We had difficulties translating "bicultural" (in the options of this item, however, we have then selected the wording with "cultural meaning" remaining embodied in the context. So, instead of trans- 
lating it into "berbudaya campuran" (having mix-culture) we translated it into "berbudaya ganda" (having or being bound in two cultures). Again, this required further assessment during the cognitive debriefing.

Final Version of the SL-ASIA Scale Indonesian Version, can be requested to the author.

\section{Closing remarks}

Language is a means of communication that is specific to each culture or ethnic group, if not to each individual (Chassany, et al., 2001). Many questionnaires have already been translated for use in other countries and/or cultures, and worldwide regulators are rightly concerned about their validity in measuring the same concepts. MAPI Research Center has stated as linguistic validation, that is the process aiming at the production of appropriate translated language versions. And this process deals with the linguistic and cultural aspects of the target language versions (Chassany, et al., 2001). Linguistic and cultural validation appears to be satisfactory for extensive use in different cultures The history or background of the instrument development were varies and tightly attached to the timeframe which can be different from time to time. The theoretical frame of different cultures leads to big differences in pulling out the meaning or appraising target of the instruments. The above example on the validation of SL-ASIA gives us a lesson learnt that more psychometric instrument may require to be undergone through cultural and linguistic validation as well. Following are some more thoughts left for further discussions in our concern, as scientists, as well as users.

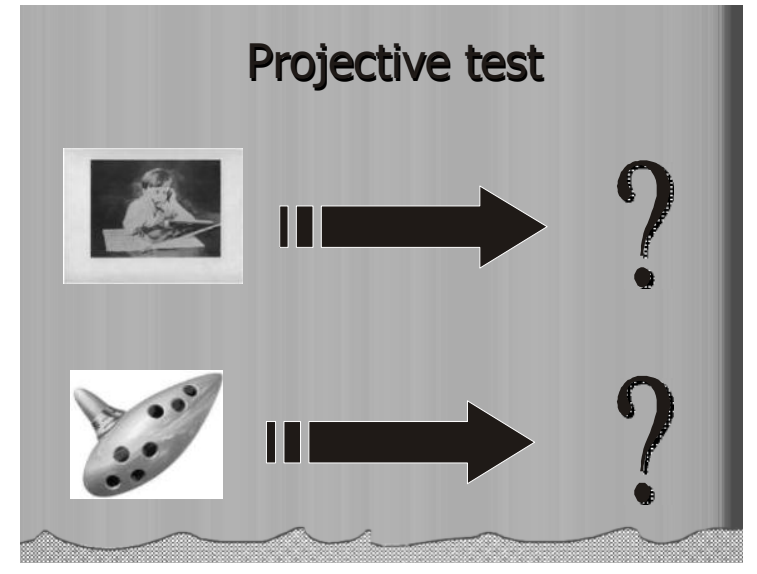

The above picture is one of the famous the TAT cards. Any response of individuals who are not able to interpret it as "A young boy looking at a violin", can be interpreted as having cognitive distortion. How come? Because most people are expected to be able to make the popular response, that is "A young boy looking at a violin". Having in mind the perspective of cognitive psychology, we can learn that: "the stronger the stimuli intrude in our mind, the stronger the memory will be shaped and the greater chance of us producing responses close to our previous experiences". And now the question is: if our exposure to the violin is not as much as the frequency of those community at the place where the TAT Cards developed (?). The answer is, quite likely, "No". And so, similar treatment (in the Western countries) should not be implemented to the similar lack of popular response in the Non-Western countries, e.g., Indonesia. The $2^{\text {nd }}$ picture stimuli is called as Ocarina, a music instrument in the South America. Some of us may not be familiar with that instrument, but the South Americans do. And therefore no similar treatment should be administered to the different communities with different exposure to such stimuli. 


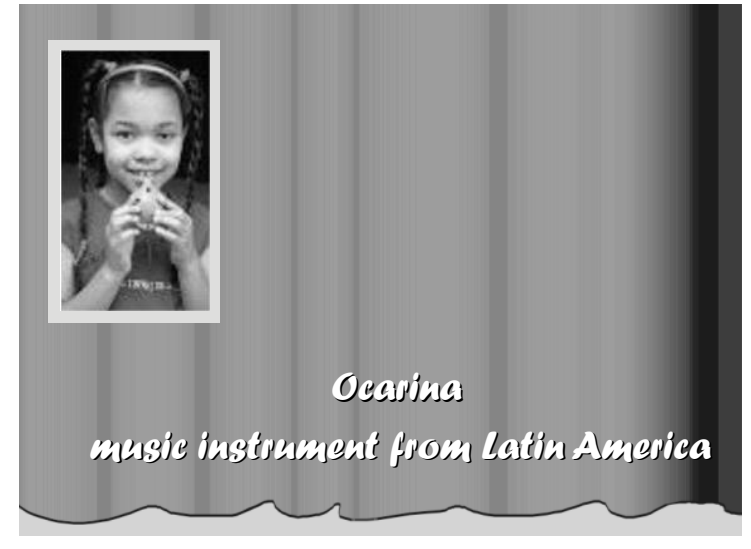

The following diagram invites us to critically think if cultural adaptation needs to be considered. The Sach Sentence Completion Test was developed in an individual culture, and being used initially in German speaking countries. In those countries, family means the nuclear family, usually consists of a mother, a father, and siblings. So, those who are not able to mention and recognize their father for example, can be interpreted as having "bad communication" with their father figure. This interpretation, however, may not be appropriate in a collective culture like Indonesia. The local communities in Indonesia have grandparents, aunties, uncles, neighbors, and even housemaids, living and staying with them a close relationship. Therefore, the absence of "father" or "mother" or whoever else in filling out the SSCT should not be judged as having "family's problem of communication. Guide of interpretation, to be relevance, should be developed and adjusted to the context of local culture using the local meaning. Otherwise, validity of the measurement is threatened.

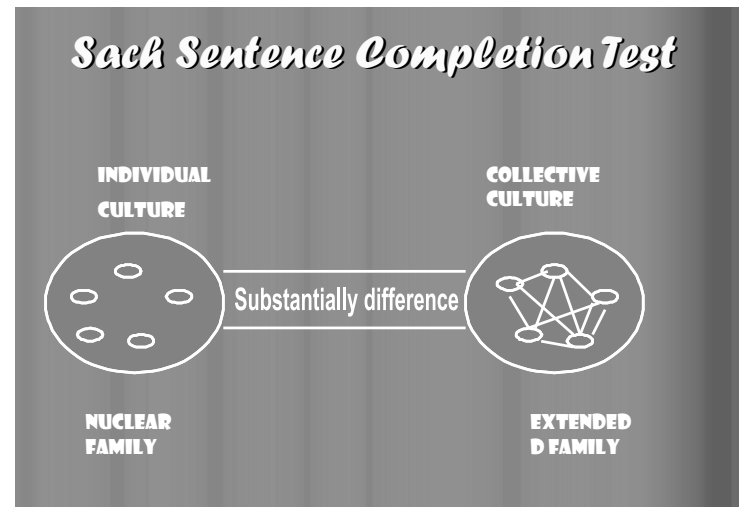

The next issues is about assessment on the "Successful Aging", using the Berliner Successful Aging, written and developed for the Berliners in Germany. One of the items is if the participant sexually still active. Minimal score applies to those who give "No" answer, and vice versa. When contextual construct of the culture implemented in this matters, similar score should not be given to Indonesian participants. This is due to the fact that elderly in Indonesia yield the believe that being a wise elder, people should better not doing sex anymore, rather than that, they are supposed to allocate more attention on preparing themselves to God (ready to death). So, the score yields from this measurement of two communities, Western and Non-Western, is not considerably equivalent, neither comparable.

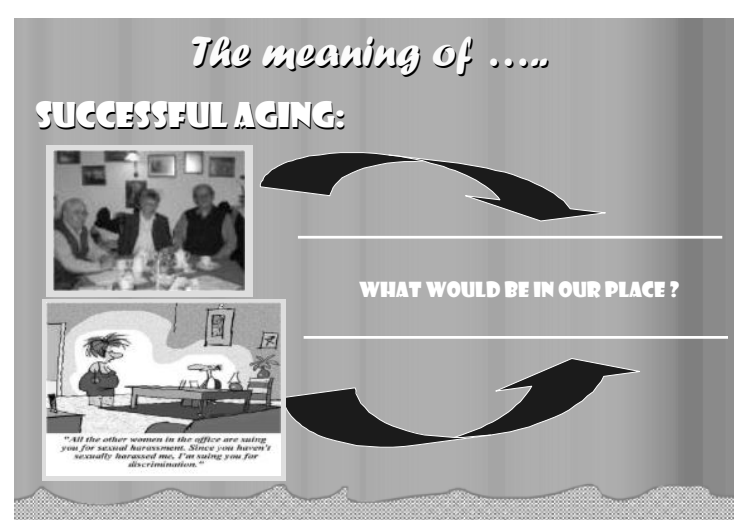


Issues to be reconsidered: wheteher or not Western and Indonesian cultures having similar meaning on depression. In countries with winter in their seasons, people are exposed to the winter weather. During winter, exposure to the sunshine is very limited. This will reduce serotonin in blood which may lead to the situation like depression. People get depressed by themselves without any causes other than the weather. In Indonesia, exposure to the sunshine is "gemah ripah loh jinawi", people get the sunshine more than enough. There is no way or circumstances where people get depressed without any reasons. With regard to this different circumstances, could we still perceive depression in similar weight between countries having winter and non winter countries?

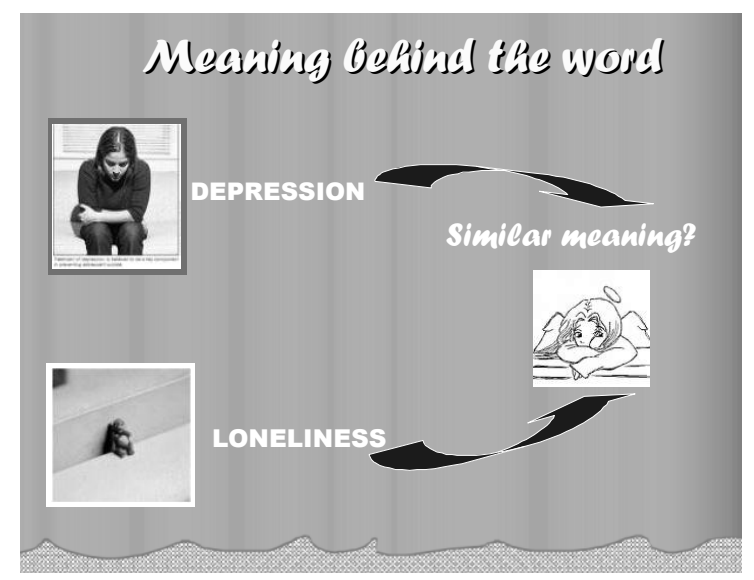

More discussions are required for issues like described in the last parts of this article. There must be more issues to be discussed in the line of cultural and linguistic validation. More works are empirically demanded in this matters.

\section{References}

Chassany O, Sagnier P, Marquis P et al, for the European Regulatory Issues on Quality of Life Assessment (ERIQA) group. Patient-Reported Outcomes: The Example of Health-Related Quality of Life - A European guidance document for the improved integration of Health-Related Quality of Life assessment in the drug approval process. DIA Journal 2001; 36: 209-238

Dion, K. L., \& Dion, K. K. (1996). Chinese adaptation to foreign cultures. In Bond, M. H. (ed.). The Handbook of Chinese Psychology, 1996. Oxford University Press, Oxford.

Dion, K.L., Dion, K. K., and Pak, A.W. (1992). Personality-based hardiness as a buffer for discrimination-related stress in members of Toronto's Chinese community. Canadian Journal of Behavioral Science, 24, 517-36.

Haudek, C., Rorty, M., and Henker, B. (1999). The role of ethnicity and parental bonding in the eating and weight concerns of Asian American and Caucasian college women. International journal of eating disorders. May,25-4-, 425-33.

MAPI Annual Report. 2002. Linguistic Validation. Annual report on the current projects of linguistic validation. MAPI Research Institut. Lyon.

Suinn, R.M., Ahuna, C., and Khoo, G. (1992). The Suinn-Lew Asian Selfidentity Acculturation Scale: Concurrent and factorial validation. Educational and Psychological Measurement, 52, 1046-51.

Suinn, R.M., Rickard-Figuroa, K., Lew, S., \& Vigil, P. (1987). The Suinn-Lew Asian Self-identity Acculturation Scale: An initial report. Educational and Psychological Measurement, 47, 401-7. 